\title{
4. Australia, Latin America and the Environment
}

\author{
James R. Levy and Peter Ross
}

\section{Introduction}

Environmental issues have taken centre stage in the globalised world of the 21 st century. There is a growing awareness and acceptance of the interconnectedness of nation states, not just at the level of trade, investment and ideas, but also at the level of the shared environmental consequences stemming from the types of development undertaken. Environmental damage in one nation state can directly affect contiguous nation states, as has been observed in the past with events such as acid rain, flooding, and nuclear fallout, but a far greater problem is the global nature of the current environmental crisis as manifested by-but not limited to-climate change and pressure on finite resources shared by various nation states. A major consequence is that the concept of national strategic interest needs to be considerably broadened. If national interest means anything then it is about the wellbeing and security, in the broadest sense, of the people who comprise a nation state. This can no longer be limited to military defence and rising living standards as measured by GDP per capita, education levels and increasing longevity, the components of the United Nations' Human Development Index (HDI). The health of the planet also needs to be included. And no one nation state can take responsibility for that. Cooperation is essential - and that cooperation must be as global as possible.

Cooperation among nation states depends upon a clear understanding of similarities and differences. A major difficulty in analysing Australian-Latin American relations in any sphere, including the environment, is that Latin America is comprised of about 20 nation states, ${ }^{1}$ each with its own peculiarities and developmental pattern, with significant differences with regard to living standards, population, natural resources, and degree of industrialisation and urbanisation. Moreover, these nation states stretch from the northern hemisphere

\footnotetext{
1 Latin America is a vague term and is generally used to refer to those countries in the Americas in which Spanish and Portuguese are official languages. Sometimes French-speaking countries are included. If all countries in the Americas south of the United States and including all of the Caribbean nations are thought of as Latin American, then the total rises to 42. For the purposes of this chapter we use Latin America to refer only to the Spanish and Portuguese speaking countries.
} 
to the Antarctic. None of them approach Australia in terms of living standards as measured by the HDI. Australia is currently ranked number two in the world, while the first Latin American country to be listed is Chile at number 43.

On the other hand, Australia and most of Latin America are situated in the southern hemisphere; many of the environmental problems the globe confronts, from climate change to serious marine pollution, emanate from the northern hemisphere. Whether the source is a poor nation, such as China, or a rich nation, e.g., the United States, the fact remains that the problem derives very largely from the northern hemisphere, not the southern. The north contributes far more than its fair share of environmental degradation and dominates such practices as polluting both the atmosphere and the oceans; the illegal, unreported, and unregulated fishing that is adding to the crisis of fish stocks; warming the climate; and enforcing economic policies that result in increasing rates of deforestation in the south.

The environment below the equator is cleaner, less polluted and possibly less exploited than that of the north. The obvious question is: why do the nations of the south allow their resources and their environment to be plundered and ruined while simultaneously suffering the deterioration of their own living conditions? The answer involves not only the political and economic: it also requires a moral understanding of just who possesses rights over the earth. Thus, the solution must involve more than Australia and Latin America: it requires a larger consensus. Fish, for example, do not know whether they are swimming in territorial waters or in the open seas. But Australia and Latin America together and with other partners can begin to articulate a common political and moral position that could serve notice that narrow economic and material interest is no longer acceptable to the southern hemisphere in protecting and managing its environment for all stakeholders.

In this chapter, we consider two issues-deforestation and the marine environment, particularly fishing - that directly affect the lives of Latin Americans and Australians. Given the overwhelming and immediate importance of addressing global warming, deforestation is the more central if not the more contentious issue because of its direct relationship to carbon emissions. As will become evident below, the possibilities of achieving cooperation between the many Latin American states and Australia on deforestation will be conditioned by the economic needs and specific strategies related to producing less carbon. As for the marine environment, the focus on fishing and the protection of whales dramatises the prospects of a finite resource seriously threatened. Much research currently concentrates on the relationship between global warming and the deterioration of the oceans. The absorption by the oceans of some 20 to 30 per cent of the carbon dioxide emitted has resulted in acidification that will affect food security, coral reef ecosystems and the deaths of some marine 
organisms. ${ }^{2}$ In addition, sea levels are rising, low-lying islands are facing submersion, and coastal environments such as salt marshes and mangroves confront severe deterioration.

Although much research is being done, the main focus is on pollution and conservation of fish stocks and whales. Nevertheless, just because the deteriorating marine environment may not be as directly determined by global warming as the terrestrial environment, the oceans remain the source of much life on the planet including, of course, our food.

Despite the obvious difficulties in achieving and maintaining cooperation between Australia and Latin America, the record is clear that both the institutions and the policies for a common southern hemisphere position on the environment can be formed. Australia and most Latin American nations cooperate on many issues in such forums as the United Nations, APEC and the World Trade Organization. Within the UN framework, for example, Australia signed the Antarctic Treaty in 1959, joining with Argentina, Brazil, Chile, Ecuador, Peru and Uruguay. These nations were among the 27 that wrote the Treaty. Australia continues as host of the Commission for the Conservation of Antarctic Marine Living Resources and has signed the Convention on International Trade in Endangered Species and the International Tropical Timber Agreement. Notably, in 1995 it convened the Valdivia Group, formally named the Group of Temperate Southern Hemisphere Countries on Environment, which includes New Zealand, Chile, Argentina, Uruguay, Brazil and South Africa. More will be said about this below. But Australia does not always cooperate on behalf of the planet. Particularly egregious examples include its stance on carbon emissions and its membership of the Miami Group of nations - Canada, Argentina, Uruguay and the United States - which has successfully frustrated the formulation of the Biosafety Protocol to the Convention on Biodiversity. ${ }^{3}$

\section{Forest management and carbon sequestration}

As a response to global warming, forest conservation, management and expansion are areas of common interest to Australia and Latin America. Carbon released as a result of deforestation constitutes about 17.3 per cent of global greenhouse gas emissions. Deforestation is most prevalent in developing countries but, until relatively recently, has also been a feature of Australian development. The causes

2 See 'Summary of the Oceans Day at Cancún, 4 December 2010', www.iisd.ca/climate/cop16, accessed 27 October 2013.

3 The Miami Group of exporting agricultural nations refuses to sign the Protocol because it seeks to restrict the trade in genetically modified crops. The irony here, of course, is Australia's ostensible cooperation with Argentina and Uruguay. Sectoral economic interests invariably trump morality and perhaps safety. 
result from the need or desire to increase production to make profits, improve living standards, pay foreign debt, and/or offset the cost of imports by means of the use and commercialisation of such natural resources as land, timber, water, minerals and oil and gas deposits.

Both Latin America and Australia possess considerable tracts of forest, a consequence of relatively late development and of relatively low population densities. These forests not only store carbon and act as carbon sinks, they are also the most bio-diverse of terrestrial environments. Even without the threat posed by global warming, a case for forest preservation is easily mounted based on the importance of biodiversity and the wellbeing of humans - many of them indigenes - currently living in, and off, the forests. This analysis, however, will focus on the issues raised by the world's response to global warming and the commonalities and differences that have resulted in Australian and Latin American initiatives with regard to forests.

All Latin American countries ratified the 1997 Kyoto Protocol. Australia did not do so until late 2007, after the election of the Labor Party to office. The reluctance of the Liberal-National Coalition government to ratify the Protocol, as distinct from signing up to it, stemmed from its belief that as a developed nation (an Annex 1 country), Australia would ultimately be required to reduce its greenhouse gas emissions. This could result in lower or negative GDP growth, and hurt the economic wellbeing of the population. The Latin American nations, on the other hand, were not required to reduce emissions since they were classified as developing countries (Non-annex 1), although by the terms of the 2007 Bali Action Plan of the Thirteenth Conference of Parties (COP) under the UN Framework Convention on Climate Change, the developing countries were strongly encouraged to take nationally appropriate mitigation actions (NAMAs). These actions, unlike those of the developed countries that ratified the Kyoto Protocol, were voluntary, in line with the principle of shared but differentiated responsibilities.

This division of the world into developed or industrialised, and developing or non-industrialised, placed Australia and Latin American nations on opposite sides of the negotiating table in climate change forums. This was most apparent at the Fifteenth COP held in Copenhagen in December 2009. The Australian negotiators, headed by Prime Minister Kevin Rudd, cooperated with the chair of the conference, the Danish Prime Minister, in an attempt to draft an agreement by which both developed and developing countries would be obliged to reduce emissions. They were not successful. Instead, in talks with Brazil, South Africa, India and China, the United States produced the non-binding Copenhagen Accord, to which some of the Latin American countries, particularly those in 
the Bolivarian Alternative for the Americas (ALBA) took strong exception on a number of grounds, including that the Accord was not arrived at democratically and that the target greenhouse gas reductions were not sufficient.

That Brazil helped to pen the final accord, even while its President, Lula da Silva, expressed the view that it was an inadequate outcome, underlines the differences amongst the Latin American countries. Of the fifty-five nation states that formally associated themselves with the Accord by submitting reduction targets for 2020 by the deadline of 31 January 2010, only two were Latin American, namely Brazil and Costa Rica. Cuba specifically stated that it would not associate. The Australian letter of association guaranteed that it would cut year-2000 emissions by five per cent, and by up to 15 to 20 per cent if major developing and developed countries committed to reduce their emissions substantially. ${ }^{4}$ Australia's position on the necessity to include all of the major national economies, whether developed or developing, in a binding agreement on the reduction of emissions of greenhouse gases has been fairly consistent over the period of the 1990s to the present. Latin American countries, while not having any unified policy on the issue, have generally not been opposed to a binding agreement, but they have all maintained that, as developing countries, the same rules should not apply to them as to the developed world. On this matter Australia and Latin America have divergent positions. However, both have a common interest in the inclusion of forest conservation and land management in the calculation of carbon emissions and sequestration for individual nation states.

The Kyoto Protocol did not approve a mechanism by which forest conservation and most land use changes could be used to generate carbon credits. This was mainly due to the technical difficulties of measuring carbon sequestration, and to the fact that deforestation was not regarded as an important source of greenhouse gas emissions in the developed world. On the other hand, afforestation and reforestation projects could qualify as carbon emission reduction schemes under the Clean Development Mechanism (CDM). Australia, however, managed to secure a special deal at Kyoto due to hard bargaining on its part, and to the determination of other countries to get as many nation states on board as possible. Whereas the average reduction of greenhouse gas emissions for developed countries for the first commitment period was 5.2 per cent below the baseline of 1990 emissions, Australia was permitted to increase its emissions by eight per cent. Moreover, Australia secured the right to include any improvements in its deforestation rate within its target. As it happened, 1990 was a peak for deforestation in Australia and represented some 30 per cent of the country's carbon emissions. Already by the time of Kyoto the deforestation rate was much lower and continued to decrease as the Federal government, in concert with state

4 UNFCCC, 'Appendix 1-Quantified economy-wide emissions targets for 2020', http://unfccc.int/files/ parties, accessed 2 February 2010. 
governments, made the reduction of deforestation the central plank in its drive to achieve its Kyoto target, despite not having ratified the Protocol. Reductions in greenhouse gas emissions in this sector permitted increased emissions from other areas including agriculture, industry, transport, mining, households and energy generation, which is heavily dependent on coal-fired power stations. In fact, such emissions increased by 26 per cent between 1990 and 2007. However, because of the offset provided by reduced deforestation, the official figures for emissions increase between 1990 and 2008 was nine per cent, very close to the target of eight per cent set for Australia at Kyoto. ${ }^{5}$ Since 2008 Australia's greenhouse gas emissions have declined slightly, keeping it within its set target.

Following Kyoto, Australia mounted a strong campaign to have the special deal it secured with regard to forest management institutionalised within the framework of the strategies endorsed by the United Nations Framework Convention on Climate Change. Many of the developed countries joined this campaign. On the one hand they were concerned about the substantial amount of greenhouse gas emissions generated by deforestation; on the other they could offset some of their own emissions by investing in forest conservation and other forestry projects in the developing countries, a strategy endorsed in a limited way at Kyoto via the 'flexible mechanisms' of emissions trading and the clean development mechanism (CDM). ${ }^{6}$ Developing countries with deforestation problems were also enthusiastic about the inclusion of forest preservation and augmentation within the parameters of the Kyoto Protocol. These pressures from both developed and developing countries resulted in the 2007 Bali Action Plan, which included the formulation of strategies for reducing emissions from deforestation and forest degradation in developing countries (REDD).

Understandably, Australia welcomed the REDD initiative because the reduction of deforestation within its own borders was the key element in its strategy to reach the targets set for it at Kyoto, and any institutionalisation of the special deal it had secured validated its environmental policies. The Bali Roadmap might also constitute a first step towards the inclusion of the developing countries into the sort of binding agreements to which most of the developed countries had agreed at Kyoto. Moreover, Australia asserted that it was in the forefront of technological development with regard to the measurement of the mitigation of climate change by means of the reduction of deforestation and of efforts made in the areas of reforestation and afforestation (REDD-plus). Australia therefore considered it was in an advantageous position to help developing countries become REDD ready and initiated bilateral International Forest Carbon projects

5 Andrew Macintosh, 'Reducing emissions from deforestation and forest degradation in developing countries: A cautionary tale from Australia', the Australia Institute, Policy Brief, No. 12, 2010, p. 4.

6 The Eliasch Review, commissioned by British Prime Minister Tony Blair is a good example of the developed world's concerns regarding deforestation. See Johan E. Eliasch, Climate Change: Financing Global Forests, London, Earthscan, 2008. 
with Indonesia (the Kalimantan Forests and Climate Partnership) and with Papua New Guinea, providing scientific, technical and analytical support to both countries. Australia also participated with the World Bank in the Forest Carbon Partnership Facility and the Forest Investment Program, hosted the second world workshop on REDD in Cairns in March 2007, and cooperated with the Clinton Climate Initiative in efforts to establish efficient and effective forest carbon measurement systems in developing countries. ${ }^{7}$ The efforts of Australia and other nations to have REDD-plus accepted as a legitimate means of reducing greenhouse gas emissions were recognised at the Copenhagen meeting, which effectively gave the green light to the strategy.

Latin American countries were also active in the push for the validation of REDD and REDD-plus. In 2005, on the initiative of Papua New Guinea's President, Michael Somare, a loose coalition of developing countries established the Coalition for Rainforest Nations to secure finance from developed countries to preserve rainforests. Of the 33 countries listed as participants, 13 are Latin American. The Coalition was instrumental in the formation of the World Bank's Forest Carbon Partnership Facility and in the push for the acceptance of the REDD program. Various developed countries, including Australia, have pledged US\$3 billion to build capacity and provide incentives to reduce rainforest destruction. The UN has commenced REDD readiness programs in Panama, Bolivia and Paraguay. ${ }^{8}$

Brazil, not a member of the Coalition, has also been active in becoming REDD ready. In the Brazilian state of Amazonas, the Juma project aims to halt deforestation, improve the wellbeing of locals, avoid the degradation of 366,151 hectares of rainforest and the accompanying release of $210,885,604$ million tons of carbon dioxide by 2050, and generate carbon credits equivalent to $189,767,027$ tons of carbon dioxide. Finance for the project comes from the state government and a range of private corporations including the Bradesco Bank and the Marriott hotel chain. ${ }^{9}$ In joining the Copenhagen Accord, Brazil pledged to reduce its carbon emissions by about 39 per cent by 2020. In effect this would be done by following the Australian path of reducing deforestation and taking other measures approved by the UN in the areas of afforestation, reforestation and land change. By 2013 government initiatives to control deforestation had had notable success, leaving Brazil well on track to meet its Copenhagen target.

7 Australian Government, Department of Climate Change, 'International Forest Carbon Initiative', http:// www.climatechange.gov.au/government/initiatives/international-forest-carbon-initiative.aspx, accessed 22 January 2010. See also Australian Government, Department of Climate Change and Energy Efficiency, 'Action under the International Forest Carbon Initiative', http://www.climatechange.gov.au/government/initiatives/ international-forest-carbon-initiative/action.aspx, accessed 14 December 2010.

8 Latin American and Caribbean Forestry Commission, 'Forests and Climate Change - With a Special Focus on Climate Change Adaptation', Twenty-Sixth Session, Guatemala City, 24-28 May 2010, FO:LACFC/2010/6, www.rlc.fao.org/es/comisiones/coflac/2010/pdf/lacfc-6e.pdf, accessed 20 June 2010.

9 Virgilio Viana, 'Seeing REDD in the Amazon', Tiempo, 73, 2009, p. 5. 
Costa Rica aims to become carbon neutral by 2020, again largely based on reducing deforestation and by planting trees. Since 2005, landowners have been paid from a variety of state revenues including a tax on fuel to conserve trees and to plant new trees. Costa Rica's policy is also predicated on both domestic and foreign corporations using carbon sequestration in the country as a means of offsetting carbon emissions within Costa Rica and abroad.

On the face of it, therefore, Australia and many of the Latin American countries have a common interest in reducing their greenhouse gas emissions by means of carbon sequestration and carbon capture associated with forests and land use. However, there are major differences that hinder cooperation. The most important of these is the nature and role of financing. Australia wants to anchor the process in a global carbon market, arguing that only a market-based approach can provide the finance and investment on the scale needed to address forest emissions. At the same time, Australia does recognise that some countries might prefer to stay with the offset system of the Clean Development Mechanism as established at Kyoto. Australia also accepts that public financing - domestic and international - is essential, especially in the early stages of countries becoming REDD ready. However, in the long term, only a carbon market will work. ${ }^{10}$ The Latin American countries in general do not agree with this stance. The most extreme position is that adopted by Bolivia and enshrined in the Cochabamba People's Agreement produced at the World People's Conference on Climate Change and the Rights of Mother Earth, held at Cochabamba in April 2010. That document absolutely rejects the use of market mechanisms to reduce deforestation and forest degradation. Moreover, it argues that the developed world is responsible for global warming and therefore owes a climate debt to the developing countries. It states that the developed countries have colonised the atmosphere. To make amends and to remedy the situation, the rich countries should pay about six per cent of their GDP to the developing countries so that they can achieve sustainable development. The developed countries should also be obliged to transfer technology associated with climate change to the developing countries free of intellectual property rights. The Agreement sheets home the blame for the environmental crisis to the capitalist mode of production. ${ }^{11}$

Bolivia's stance is undeniably extreme within Latin America; however, almost all Latin American nations reject the notion that a global carbon market will be beneficial to them. From Mexico to Brazil, governments have voiced their belief that there needs to be a transfer of funds and technology from the developed to the developing world if forests are to be saved and forest degradation reversed.

10 Australian Government, 'Australia's proposal for a forest carbon market mechanism', March 2009, http:// www.climatechange.gov.au/government/initiatives/unfccc/submissions.aspx, accessed 22 February 2010.

11 World People's Conference on Climate Change and the Rights of Mother Earth, http://pwccc.wordpress. com/, accessed 17 August 2010. 
Even the Copenhagen Accord recognised this, at least to some extent, and promised the transfer of some US $\$ 30$ billion to the developing world over the period 2010-2012, and US\$100 billion annually by 2020, only half of which would be derived from the carbon market. In 2008 Brazil unilaterally established an Amazon Fund, and called on the developed nations to deposit US\$21 billion to fund rainforest preservation. Only Norway responded, promising some US\$1 billion. Funds advanced to date have been used to control bushfires, compensate landowners, resolve land ownership disputes, and educate landowners on sustainable farming and pastoral activities.

The COP16 global climate summit held at Cancún towards the end of 2010 essentially reiterated the determinations of Copenhagen. With regard to forests, the objective of Australia and of many of the Latin American countries to have REDD made a fully accepted part of the world's strategy for greenhouse gas reduction was achieved. How REDD projects would be funded, however, was not clarified. The most recent climate summit held in Dohar in November 2012 again did not resolve disputes over funding.

There is now an opportunity for Australia and Latin America to forge a much greater bond in the pursuit of carbon sequestration and carbon capture by means of forest and land management. Australia has considerable scientific expertise in the measurement of carbon sequestration and could transfer this technology to the Latin American countries. Such transfers were called for in the final documents of the Cancún talks, but how these would be financed was not made clear. To date, Australia has made such transfers only to its immediate neighbours of Indonesia and Papua New Guinea. However, in the interest of forging closer relations within the southern hemisphere, Australia would do well to shore up and expand its connections with the Latin American countries by means of the transfer of clean energy knowledge, especially in the domain of forest management.

Australia could also take note of some of the concerns raised by Bolivia and others, especially with regard to the treatment of forest peoples, including indigenes. In pushing for a carbon market, Australia favours private ownership or control of resources. This is far from the position of the Bolivian government, which supports state and communal ownership. Bolivia has also raised the issue of the treatment of environmental refugees and is concerned about the barriers placed in their way in accessing other countries, particularly by the developed nation states. Given that Australia has one of the highest per capita greenhouse gas emissions of all the nation states, and that it has been recently reprimanded by the United Nations for discrimination against its Aboriginal population and for its treatment of refugees, it is hardly in a position to adopt a morally superior position, as it has a tendency to do. Moreover, there is much to be learnt from 
Latin America with regard to the sustainable use of forests, and a fruitful interchange among the countries of the southern hemisphere, unhindered by free market ideology, is imaginable and desirable.

\section{The marine environment}

Perhaps the most obvious place where Australia, Latin America and other nations in the south can meet is in the Pacific, Indian and southern oceans. Among the critical issues we confront in these spaces are whaling, over-fishing, pollution of the marine environment, illegal, unreported and unregulated fishing, and threats to the survival of fish and bird species. With the possible exception of shipping, fishing is economically the most important oceanic activity to Australia, which may help to explain the government's keen interest in the marine environment.

Although the fishing industry is not a huge contributor to the nation's total production it is nevertheless a significant participant. According to the most recent figures available, in 2010-11 the gross value of Australian fisheries amounted to \$A2.23 billion, of which \$A948 million came from aquaculture and \$A1.3 billion derived from the wildcatch sector. The contribution of aquaculture has increased at the expense of wildcatch. ${ }^{12}$

Australian fish exports are almost entirely of edible products sent to Hong Kong and worth \$A539 million; to Japan worth \$A269 million; and to China \$A146 million. Pearls are the second most important export by value (\$A241 million) after rock lobster (\$A369 million). ${ }^{13}$ The sources of imports are Thailand (\$A297 million), New Zealand (\$A207 million), Vietnam (\$A142 million) and China (\$A133 million). The imported products include canned fish, frozen fish fillets, fresh, chilled or frozen prawns, pearls and canned crustaceans and molluscs. ${ }^{14}$ These statistics suggest the limited importance of fishing to the Australian economy; in fact the industry has stagnated during the last decade. One welcome statistic is the decline in the number of foreign fishing vessels caught illegally in Australian waters during 2011-12: it is at a 19-year low. ${ }^{15}$ Based on available evidence it would appear that within the waters administered by the Australian Fisheries Management Authority, the fishing industry is carefully supervised, thanks in part to border security, in cooperation with private industry. Consequently, the Fishery status reports of the Department of Fisheries and Aquaculture assures us that of the fish stocks assessed, 77 were not subject

12 Australian Bureau of Agriculture and Resource Economics, Australian Fisheries Statistics 2011, December 2012, p. 1. abare.gov.au. Since 2000-01, the 'real values of Australian fisheries exports fell by 57 per cent (\$A1.6 billion)'.

13 Ibid.p. 22.

$14 \quad$ Ibid.p. 23.

15 Australian Fisheries Management Authority, Annual Report 2008-09, Canberra, 2009, p. 2. 
to overfishing, 58 were not overfished, six were subject to overfishing, and 11 were overfished. In short, Australian fish stocks are carefully monitored and ecologically in relatively good condition - that is, their biomass quantity in general is at low or moderate risk. ${ }^{16}$

Fishing plays an important part in the economies of several Latin American nations, particularly in Chile and Peru. In 2009, Chile claimed seventh place among the world's largest exporters of fish and fish products by value (\$US3,606,328,000) and Peru came in at fourteenth (\$US2,208,874,000). Among the nations that concern us in this chapter, Ecuador, Argentina, Australia, New Zealand, Mexico, South Africa and Brazil followed in that order according to the value of exports among the world's 50 principal fishing nations. ${ }^{17}$ Chile's exports include both fish and processed products, mostly fishmeal, while those of Peru are almost entirely of fishmeal. Thus, the contribution of fishing to the economies of both countries is significant - it is no wonder that Chile and Peru along with Ecuador initiated the movement to establish the 200-mile territorial limit for fishing in the early 1950s.

However, there are difficulties and challenges facing the Australian industry and fishing industries elsewhere that cannot be easily overcome. For example, climate change: the Annual Report 2008-2009 of the Australian Fisheries Management Authority noted that it is carefully monitoring research on the marine environment and fisheries because the science predicts that 'climate change will affect the distribution of fish stocks over time'. ${ }^{18}$ In its Annual Report 2011-2012 the Authority said that climate change is 'already affecting fishers', although at present it does not anticipate any immediate action due to present management of the fisheries. ${ }^{19}$

Another issue concerns floating marine debris that accumulates in 'the eastern-centre region of the South Pacific subtropical gyre' and is locked in. ${ }^{20}$ The debris is not only an aesthetic issue: the authors cite an article that estimates the deaths of more than 100,000 sea creatures, including turtles, because they have consumed or been entrapped by plastic bags or other debris. Nor is there any certainty of what happens to the marine environment when the debris slowly disintegrates and chemicals are released into the ocean. The pollution problem that threatens fishing extends also to birds and indeed much of the marine ecosystem. An example close to home is the effects on the Great

\footnotetext{
16 Australian Government, Department of Agriculture, Fisheries and Aquaculture, Fishery status reports 2011, 18 December 2012 www.daff.gov.au/abares/publications_remote_content/public, accessed 27 October 2013.

17 See FAO Yearbook of Fishery Statistics 2010, Summary Tables, p. 15. ftp://ftp.fao.org/fi/stat/summary, accessed 27 October 2013.

18 Australian Fisheries Management Authority, Annual Report 2008-2009, Canberra, 2009, p. 3.

19 Australian Fisheries Management Authority, Annual Report 2011-2012, Canberra, 2012, p. 4.

20 Elodie Martinez, et al., 'Floating marine debris surface drift: Convergence and accumulation toward the South Pacific subtropical gyre', Marine Pollution Bulletin. 58, 2009, pp. 1347-55.
} 
Barrier Reef of herbicide, pesticide and fertilizer run-off from farming. Even mining contributes to the threat. ${ }^{21}$ Another pollutant particularly serious for sea creatures is discarded fishing gear, especially nets that entrap their victims. But the greatest criminal by far is plastic; a survey of the ten most common items collected in South America in 2005 found plastic containers and lids at the top: in Peru they accounted for 49 per cent of the debris, in Chile about 70 per cent, while in Ecuador cigarettes and their filters made up over 55 per cent. ${ }^{22}$ Much of the plastic found as waste originated in the northern hemisphere. Europe, North America and Japan account for about 60 per cent of plastic production, but developing countries find that their lower wages are increasingly attractive to plastics producers who are shifting operations to such nations: '[I]n the south-eastern Pacific Ocean, surveys of plastic pollution near the coast, including fragments of foamed polystyrene, plastic bags, and food sacks from salmon farms identified aquaculture as the most significant contributor' ${ }^{23} \mathrm{On}$ the most remote beaches of Tasmania clean-up volunteers collected 35,777 bits of debris in one week, including an Argentine rugby ball, a Brazilian Coca-Cola bottle cap, and plastic energy drink bottles from South Korea. ${ }^{24}$

Overfishing threatens the economic survival of the populations who depend on this finite resource. The notion that fisheries policies should reflect social needs is all but lost among the countries of the north. As David Symes and Jeremy Phillipson write:

Unlike most Third World countries where social issues-including food security, employment, fair trade and the protection of individual and community fishing rights - are very much to the forefront of fisheries development, in Europe, North America and Australasia the social objectives of fisheries policy have all but disappeared from view. Although disturbing, this turn of events is not altogether surprising. One does not have to look very far for an explanation of the obscuring of the social dimension in fisheries policy.

21 'From Catchment-to-reef continuum: Case studies from the Great Barrier Reef. A special issue', Editorial, Marine Pollution Bulletin 2012, 65, 2012, p. 77. Elsevier: www.elsevier.com/locate/marpolbul, accessed 27 October 2013.

22 Scientific and Technical Advisory Board, Marine Debris as a Global Environmental Problem, Washington, DC November 2011, p. 8.

23 Marcus Erikson, et al., 'Plastic pollution in the South Pacific subtropical gyre', Marine Pollution Bulletin, 68, 2013, pp. 71-2, www.elsevier.com/locate/marpobul, accessed 27 October 2013.

24 Andrew Darby, 'Fight to turn tide of trash crashing on wild shores', The Sydney Morning Herald, 12-13 April, 2013, p. 7. http://www.smh.com.au/environment/conservation/fight-to-turn-tide-of-trash-crashingon-wild-shores-20130412-2hquu.html, accessed 27 October 2013. 
Even in the developed world formal fisheries policies and comprehensive management systems, as distinct from piecemeal regulation, are little more than 30 or 40 years old. They were born of a growing concern for the depletion of commercially valuable fish stocks through overfishing. ${ }^{25}$

Perhaps the greatest barrier to doing anything about the situation is the law of the sea that enshrines equal access to the oceans beyond the 200-mile limit. Increasingly in various international forums, however, discussions address the need to find a way of reconciling the oceans as 'commons' with the requirements of sustaining and improving the marine environment. ${ }^{26}$

A list of just the major issues relating to fishing reveals the daunting complexity of the matter as well as the precarious future of the entire marine environment. Overshadowing all the subsidiary problems is that of over fishing and the probability that about 60 per cent of fish species are in great or significant danger of extinction. In spite of the United Nations Fish Stocks Agreement adopted on 4 August 1995, the situation is deteriorating due to illegal, unreported and unregulated fishing, the flag of convenience vessels that permit irresponsible fishing, the huge quantities of unwanted marine life that are destroyed and thrown back into the sea-so-called by-catch - and freedom of the high seas that raises all sorts of problems in the regulation and enforcement of agreements among states and multinational bodies. And if these problems are not difficult enough, then there are debates over technical issues such as obtaining reliable data on the biomass of species; use of proper fishing equipment; differences between developed and developing nations over what, if any, advantages should be allowed the latter in fishing on the high seas; the difficulties of reconciling the conservation measures between those applicable to a country's exclusive economic zone - the 200-mile limit - and the high seas; and conflicts between artisanal and industrial fishers.

The solutions are as difficult as the problems. For example, on the question of whaling-discussed below-Australia and the Buenos Aires Group of nations together resisted the attempt to reintroduce commercial whaling at the June 2010 meeting of the International Whaling Commission. Instead, they supported the establishment of a South Atlantic sanctuary for whales. Another recent example of the common search for solutions is the agreement on Port State Measures to prevent, deter and eliminate illegal, unreported and unregulated fishing. ${ }^{27}$ This

25 David Symes and Jeremy Phillipson, 'Whatever became of social objectives in fisheries policy?', Fisheries Research, 95, 2009, pp. 1-5. http://www.elsevier.com/locate/fisheries, accessed 27 October 2013.

26 See, for example, UN General Assembly, Sixty-fifth session, Agenda item 75 (a), Oceans and the law of the sea, 'Letter dated 16 March 2010 from the Co-Chairpersons of the Ad Hoc Open-ended Informal Working Group to the President of the General Assembly'. A/65/68.

27 'Port State' refers to the port of the country where the catch is landed. See UN, FAO, Fisheries and Aquaculture Department, 'Port State Measures Agreement.' http://www.fao.org/fishery/topic/166283/en. The following countries have acceded: Myanmar and Sri Lanka; Norway has ratified, and the EU has approved. Twenty-five States and the EU have signed, as has Australia. Signing is insufficient to give the agreement force. 
agreement establishes a regime that will make it possible to refuse port entry to fishing vessels that cannot meet certain specifications regarding the origins of the catch, the kind of equipment used, authorisation to fish in certain waters, and so on. Approved in November 2009, the original signatories included Australia, Brazil, Chile, New Zealand, Peru and Uruguay. Since then, only Chile has ratified the agreement that requires the ratification, acceptance, approval or accession of the 25 states and regional economic integration organisations. Effective administration by port states is seen as one of the best strategies available to control illegal, unreported and unregulated fishing - if, of course, the port states possess the capacity and the will to enforce the agreement.

Although published by the Australian Department of Agriculture Fisheries and Forestry in 2005, the more detailed description and analysis of widespread illegal, unreported and unregulated fishing on the high seas retains its validity even today. ${ }^{28}$ The declining, even threatened, stocks of popular edible fish including Atlantic, Pacific and Indian Ocean tuna, and the Patagonian toothfish in the southern ocean, entice fishers to defy governments, international agreements and legitimate fishing enterprises in search of the highly priced fish. Many, probably most, of the vessels involved are registered under flags of convenience issued primarily by Belize and followed by Honduras, Panama, and St. Vincent and the Grenadines. However, even the landlocked countries Bolivia and Mongolia have issued such flags, albeit in minor quantities. ${ }^{29}$ By mid-2005, over 1,000 large-scale fishing vessels sailed under flags of convenience, while the group for which flags are unknown to insurers increased in number since 1999 by 50 per cent. Altogether, about 15 per cent of the global large-scale fishing vessel fleet flew under flags of convenience, with Spain and Taiwan being the major profiteers. This illegal, unreported and unregulated fishing has become widespread as coastal waters are fished out or are declared highly protected. The report concludes: 'Unfortunately, with some exceptions, the international community is losing the battle to effectively conserve and manage fisheries on the high seas'. ${ }^{30}$ The Australian fishing industry and the government have worked hard to protect their own region: during 2011-12, some 12 foreign fishing vessels were caught, down from 14 during 2010-11, 23 in 2009-10, and 27 in 2008-09. ${ }^{31}$ Of the 12 fishing vessels apprehended in 2011-12, five were destroyed in the Authority's land-based facilities, six were disposed of at sea, and one sank after the crew was removed.

\footnotetext{
28 See M. Gianni and W. Simpson, 'The Changing Nature of High Seas Fishing: how flags of convenience provide cover for illegal, unreported and unregulated fishing', Australian Department of Agriculture, Fisheries and Forestry, Canberra, 2005.

29 Ibid. p. 4.

$30 \quad$ Ibid. p. 6.

31 Australian Fisheries Management Authority, Annual Report 2011-2012, Canberra, 2012, pp. 19, 26.
} 
As southern hemisphere countries that border the Pacific Ocean, both Peru and Chile possess fishing industries that suffer periodic crises related to the availability of fish stocks; when these stocks decrease, they cause industrial over-capacity, especially in the production of fishmeal. This, in turn, causes conflict between local, artisan fishers and the large, industrial firms. In the case of Peru, since the 1960s fishing interests and the government have experienced great difficulties in finding a compromise because of nationalism, private sector demands over the size of quotas and profitability in general, and the government's interests to maintain the stocks of anchovies that produce state revenues. In 1998, the Peruvian government allowed local artisan fishers to catch anchovies and, although strict limits were placed on the size of the catch, it nevertheless led to over-capacity. That challenged the profitability of the large industrial fishers. ${ }^{32}$

In Chile local fishers criticised the government during 2007 for allowing industrial fishers to over-fish the stocks of hake, the biomass of which in 2002 was estimated to be roughly 1.5 million tons, but by 2007 had fallen to 272,000 tons. The spokesperson for the artisan fishers called for the government to protect both the fish and the small enterprises. The Chilean senator who attended the protest meeting agreed that the problem existed but made very clear that nothing would be done about it in the foreseeable future. He commented: 'There is a lack of political will to resolve the problems of the fishing industry because the state is trapped in a tangle of interests. Conservation today is not oriented to the fish, but instead to the industrial fishing companies. ${ }^{.33}$

At the moment of writing, the marine issue of greatest popular interest in the southern hemisphere is whaling. It attracts a huge audience in Australia and the three major political parties agree that whaling should be stopped. Because Japan is seen as the major whaling nation, along with Norway and Iceland, the tension between the pro- and anti-whaling nations also suggests strong differences between the hemispheres. On the question of whaling, the once solid front of southern hemisphere nations that called for immediate cessation of whaling in the International Whaling Commission has broken down because of the whaling nations' enduring refusal to cease killing whales. Thus, in order to break the deadlock and the continued whaling activity, the government of New Zealand recently proposed a compromise that would allow phasing-out of whaling over a ten-year period. The Australian government's position is based

\footnotetext{
32 Martín Aranda, 'Developments on fisheries management in Peru: The new individual vessels quota system for the anchoveta fishery', Fisheries Research, vol. 96, issues 2-3, March 2009, pp. 308-12. For an earlier but more comprehensive statement of the problem, see Alonso Aguilar Ibarra, Chris Read and Andy Thorpe, 'The Political Economy of Marine Fisheries Development in Peru, Chile and Mexico', Journal of Latin American Studies, vol. 32, 2000, pp. 503-27.

33 Steve Anderson, 'Chilean coastal fishermen protest depletion of hake', The Santiago Times, 26 October, 2007. http://www.santiagotimes.cl/index, accessed 2 October 2011.
} 
on former Prime Minister Kevin Rudd's promise to take the Japanese government to the International Court of Justice (ICJ) to stop scientific whaling while phasing out commercial whaling altogether over a five-year period. Although according to Canberra the New Zealand compromise would undermine the case before the International Court, ${ }^{34}$ the Australian government has since taken the case to the ICJ, with closing arguments heard on 16 July and judgement expected in late $2013 .^{35}$

A strong base now exists for cooperative action between Australia and the South American nations. Since 2000 Australia and New Zealand have supported a proposal for a South Pacific Whale Sanctuary and, more recently, a similar proposal for a South Atlantic Sanctuary instigated by Argentina and Brazil. In February 2009, the then Australian Minister for the Environment, Heritage and the Arts, Peter Garrett, offered a package of proposals that included reform of the gridlocked International Whaling Commission, the funding of a six-year program to improve non-lethal research on whales, and the establishment of a Southern Ocean Research Partnership to which Argentina, Brazil, Chile and New Zealand are committed. ${ }^{36}$ Meanwhile, the Buenos Aires Group is 'setting broad and joint research priorities for marine mammals in South America' ${ }^{37}$ Among the participants in the Workshop that convened to plan research activities were Argentina, Brazil, Chile, Costa Rica, Mexico, New Zealand, South Africa and Uruguay. Also attending were scientists from France, Italy and the United States. ${ }^{38}$

Cooperative research progresses: for example, the Southern Ocean Research Partnership convened the Living Whales Symposium and Workshop in Puerto Varas, Chile during 27-29 March 2012, which attracted 124 participants, some of whom came from Colombia, Ecuador, Mexico, Panama and even land-locked Paraguay. The conference dealt with the development and application of new non-lethal research methods in a variety of activities related to whales. Current

34 Lenore Taylor, 'Whaling compromise would break election promise', The Sydney Morning Herald, 3 April 2010, http://www.smh.com.au/environment/whale-watch/whaling-compromise-would-break-electionpromise-20100402-rjy5.html, accessed 27 October 2013.

35 Andrew Darby, 'Decision will bring tectonic shift in whaling politics.' The Age, 17 July 2013, http:// www.theage.com.au/federal-politics/political-opinion/decision-will-bring-tectonic-shift-in-whaling-politics20130717-2q351.html\#ixzz2cYh2HIWE, accessed 27 October 2013. At time of publication (December 2013), no judgement had been rendered - ICJ, 'Whaling in the Antarctic (Australia v. Japan: New Zealand Intervening): Conclusion of the Public Hearings: Court to Begin its Deliberations', Press Release No. 2013/16, International Court of Justice, The Hague, 17 July 2013: http://www.icj-cij.org/docket/files/148/17464.pdf, accessed 6 December 2013.

36 Peterr Garrett, 'Speech: The Future of International Whale Conservation, Lowy Institute', Sydney, http:// www.petergarrett.com.au, 18 February 2009.

37 Draft Report of the Planning Workshop of the Southern Ocean Research Project, p. 4. Workshop held in Sydney, 23-6 March 2009.

38 Australian Marine Mammal Centre: Southern Ocean Research Partnership. http://www.marineanimals. gov.au/southern-ocean-research-partnerships-sorp, accessed 27 October 2013. 
research projects of the Partnership involve the Antarctic blue whale, the foraging ecology and predator-prey relations between whales and krill, and the behaviour and abundance of humpback and killer whales in the Southern Ocean. ${ }^{39}$

At the International Whaling Commission meeting in Morocco in June 2010, Australia staved off the threat to abandon the moratorium on commercial whaling. Minister Garrett's press release revealed his satisfaction with the results of the tense and difficult meeting while emphasising the role of the southern hemisphere nations in the cause of further research and conservation. He noted the progress in the formulation of the IWC's whale conservation management plans and the development of a research program focused on non-lethal scientific research: 'We will continue to work closely with other conservation-minded countries to finalise regional whale conservation management plans for some of the world's most threatened whale species, including South American southern right whales and western gray whales. ${ }^{40}$

Having surveyed some of the environmental issues concerning fishing and whaling that affect Australia and Latin America, and the mechanisms employed to deal with them, we turn now to the means by which more effective action can be taken to protect the environmental interests of Australia and Latin America. It is not as if the Latin American nations with maritime interests have neither the experience nor the capacity to protect their resources. They are, of course, parties to many of the same international agreements as Australia. Moreover, these countries have developed national institutions to protect and manage their own maritime resources within territorial waters. Notably, the most important of such instruments, the 200-mile limit, was the result of a collective effort between Ecuador, Peru and Chile that issued the Santiago Declaration in 1952 claiming a 200-mile boundary for fishing activities. This limit is now widely accepted.

The constitutions of Latin American states generally recognise the subsoil as inalienable to private ownership, a principle extended to the seabed under the territorial waters up to 12 miles from shore. Thus, it is clear that national governments in Latin America are responsible for the management of coastal waters and are allowed to concede to private interests rights to exploit resources, as well as to protect them. As might be expected, the arrangements vary from state to state according to the situation, but the machinery for managing the marine environment in Latin America clearly exists.

Ecuador, for example, with a major fishing industry and the treasured Galapagos, has established seven Zonas Especiales de Manejo (Special Management Zones) wherein any activities such as fishing must conform to the zone's management

39 Australian Government, Department of Sustainability, Environment, Water, Population and Communities, Australian Marine Mammal Centre. www.marinemammals.gov.au/home, accessed 27 October 2013.

40 Garrett, Peter, http://www.environment.gov.au/minister/garrett/2010. Media release 28 June 2010. 
plan. ${ }^{41}$ Mangroves cannot be commercially exploited, although local ancestral communities can develop aquaculture under agreements known as Sustainable Use and Custody of the Mangroves. As for the Galapagos, a marine reserve, the only fishing permitted is limited to artisanal, local fishers for sustainable consumption. Larger vessels are allowed under a license system but all fishermen must be members of the applicable trade union.

Chile's very long Pacific Ocean coastline, its Antarctic claims, and Easter Island render it largely unable to manage the exclusive economic zone and its proximate high seas. The management of resources up to 12 miles out to sea and the implementation of controls over pollution are assigned to the Marine Subsecretary under the Ministry of National Defence and to the General Directorate of the Marine Territory and Merchant Navy. Responsibility for the protection of marine fauna and aquaculture development lies with the National Fishing Service. Chile actively involves the private sector in development of ecotourism and conservation of the ecosystem through a system of concession and authorisation. The Marine Coastal Protected Areas program is a governmentbacked initiative collaborating with the private sector to implement a project entitled Conservation of the Biodiversity of Global Importance along the Length of the Chilean Coast. ${ }^{42}$ The examples of Chile and Ecuador are but two among the Latin American states that have evolved means for protecting their marine environment and that suggest possibilities for cooperation with Australia not only in scientific research but also perhaps in management practices and in technological exchange.

In May 2010, the UN hosted in New York a review of the current situation related to the Agreement on the Conservation and Management of Straddling Fish Stocks and Highly Migratory Fish Stocks. ${ }^{43}$ The summary of the review reveals clearly the current situation: there is some hope and many perils for straddling and migratory fish. Crucial to the hopes for achieving satisfactory outcomes for arresting the decline in fish stocks are the performance of the Regional Fisheries Management Organizations. Numbering 17 at last count, these organisations are responsible for implementing the Agreement on the Conservation and Management of Straddling Fish Stocks and Highly Migratory Fish Stocks, which entered into force in 2001. As of March 2010, 77 states have ratified it, including Argentina, Australia, Brazil, Costa Rica, New Zealand, Panama, South Africa and

\footnotetext{
41 See 'Ecuador Analysis', Marine Conservation Agreements: a Practitioner's Toolkit, http://www.mcatoolkit. org/Country_Analyses/Ecuador.html, accessed 27 October 2013.

42 Ibid.

43 The summary of the meeting can be found in 'Summary of The Resumed Review.

Conference of the UN Fish Stocks Agreement: 24-28 May 2010', Earth Negotiations Bulletin, vol. 7, no. 65, 31 May 2010. http://www.iisd.ca/download/pdf/enb0765e.pdf, accessed 27 October 2013.
} 
Uruguay. ${ }^{44}$ There was agreement that a number of the Management Organizations needed to improve their performance, but some disagreement emerged as to how this might be achieved. The vigorous participation of the Latin American nations, particularly Argentina, Brazil, Chile and Peru, revealed: the need for improvement and expansion of scientific information - something many developing countries cannot afford; the complexity of reconciling the conservation measures in the exclusive economic zones with their high seas obligations; the need to expand membership of the South Pacific Regional Management Organization; and the responsibility of states over fishing vessels flying their flags. Two issues elicited clear conflict: the allowances made to developing countries in fishing on the high seas for which Brazil and Peru argued strongly-Australia was opposed; and the question of how to monitor, control, survey and enforce agreements. The Latin American participants asserted that they do not have the resources, financial or technological, to be as effective as required. In addition, they face domestic divisions between the demands of local industries, artisanal fishers, state revenues and the power of the major industrial fishers including China, Japan and Taiwan. The Latin American countries called for financial assistance to develop their capacities in these areas and resented the admonitions of some of the developed nations to strengthen the performance of the applicable Regional Fisheries Management Organization. Indeed, the Argentine delegate declared the recommendations adopted at the meeting unacceptable partly because there was no discussion of the provisions of the original Agreement. On this specific criticism the delegates of Mexico and Ecuador voiced agreement.

Despite the tensions, however, the participants achieved substantive accord on many issues such as collecting and submitting data on fisheries, the implementation of an ecosystem approach to assess and manage fish stocks, the enforcement of the existing prohibition of shark finning, improving the structures and performances of the Regional Management Organizations, the support of measures to prevent the landing of illegally caught fish, and control of the trans-shipment of catch on the high seas that evades the landing of catch at ports, thereby enforcing the agreements concerning illegal, unreported and unregulated fishing.

\section{Conclusion}

To assert a political and moral position regarding the environment of the south, a potentially powerful and effective institution already exists that deserves far more nurturing and attention than it presently receives: the Group of Temperate

44 Patricia Lee Devaney, 'Regional Fisheries Management Organizations: Bringing Order to Disorder', http:// www.pon.org/downloads/ien14_4Devaney, accessed 27 October 2013. 
Southern Hemisphere Countries on Environment, known also as the Valdivia Group after the city in Chile where the members first met. Formed in response to an initiative of the Australian government in 1995, its membership included New Zealand, Chile, Argentina, Uruguay and South Africa. Brazil joined the Group in 1997. ${ }^{45}$ At the inaugural meeting, six working groups were formed to work on biodiversity, climate change, forests, ozone, chemicals and desertification.

Implied in the formal title of the Group are a number of ideas worthy of analysis here. First is the notion that the member nations recognise a kind of stewardship over the southern hemisphere environment. When opening the fourth meeting of the Group's Coordinating Committee in Wellington, New Zealand in 1998, Don MacKay, then Deputy Secretary of the Ministry of Foreign Affairs and Trade, noted that the Group's geographical position in the world provided members with a unique outlook in comparison with northern hemisphere neighbours. ${ }^{46}$ Second, the name of the Group defines the existence of a southern hemisphere community that possesses its own characteristics and interests. On environmental issues, the implications are clear not only for the economies of the members of the Group and of the hemisphere, but also for the globe in such activities as fishing and forestry: resources must be carefully managed; consumption by the rich needs to be restricted. A third implication in the title concerns use of the word 'Temperate'. It refers to more than the climate; rather, in historical and development studies, these nations have been called 'lands of recent settlement,' associated with a temperate environment which in turn seeks to imply that they are more European, more developed economically than tropical southern hemisphere countries. Thus, Australia is not as different from its South American temperate partners as language and culture may indicate. ${ }^{47}$

All this could mean, if explored, the beginnings of a political community centred on issues of environmental protection and security. Alexander Downer, then Minister of Foreign Affairs and Trade in the Coalition government under Prime Minister John Howard, was an enthusiastic supporter of the Group in the mid-1990s. As recently as 2004, the Australian Labor Party endorsed the Group in its national platform: 'Labor will work to enhance the role of the Valdivia Group of Temperate Southern Hemisphere Countries in giving voice to southern hemisphere interests in international environment meetings' ${ }^{48}$ Unfortunately, the Valdivia Group has disappeared from view. We have been unable to find

45 To date, the only comprehensive article concerning the Valdivia Group is by Klaus Dodds, 'The geopolitics of regionalism: the Valdivia Group and southern hemispheric environmental co-operation', Third World Quarterly, vol. 19, no. 4, 1998, pp. 725-43.

46 Closing Statement of the Fourth Meeting of the Coordinating Committee of the Valdivia Group, Wellington, 24-5 June 1998. http://www.dfat.gov.au/environment/valdivia, accessed 27 October 2013.

47 Strictly speaking, Brazil, Peru and Chile are not considered 'regions of recent settlement' although Brazil might be. Among the qualifications is heavy European immigration during the 19th and early 20th centuries. 48 Australian Labor Party, National Platform and Constitution 2004, p. 243. http://www.alp.com, accessed 27 October 2013. 
any documentation related to its activities in recent years. It has achieved limited success: on the issue of ozone depletion the campaign resulted in the production of a clean technology that admittedly was the initiative of the north. The Group also produced an Agreement on the Conservation of Albatrosses and Petrels. Although the problem of bird mortality caused principally by longline fishing was recognised in the early 1990s, not until 1998 did serious work begin after the Wellington meeting of the Valdivia Group heard a paper on the topic presented by Australian scientists. ${ }^{49}$ By 2001 the Agreement opened for signatures, and by 2004 the necessary signatories to enter the Agreement into force existed: Australia, New Zealand, and South Africa within the Valdivia Group, and joined by Ecuador and Spain. In 2006 Chile, Peru, France and the United Kingdom signed, and Argentina's signature was imminent.

In the light of the Agreement and in the aftermath of Copenhagen it is time to revisit the Valdivia Group, to explore the possibilities of using it to forge stronger political and environmental ties with Latin America and, at the same time, to define a community of the south in which common interests are acknowledged and made known to the polluters of the north. This requires Australian leadership through a commitment to invest resources in sharing technology, for example, and the development of research capacities among the members, and even the development of means to enhance compliance with the laws and agreements that already exist. The environmental issue cannot be neatly split off from the political, economic and social issues - or, indeed, from the moral and ethical. If an expanded Valdivia Group can marshal its strengths - at this moment, primarily scientific - to articulate a strong message, both political and moral, very likely it would have a significant effect on the entire world.

In light of the catastrophe in the Gulf of Mexico caused by careless oil drilling practices, attention should be drawn to recent exploratory drilling in the waters off the Malvinas (Falklands) in the southern Atlantic Ocean.$^{50}$ It is dangerous on environmental grounds and, given the turbulent history of the islands, politically short-sighted. This is a moment when the south needs the Valdivia Group.

49 J. Cooper, et al., 'The Agreement on the Conservation of Albatrosses and Petrels: Rationale, History, Progress and the Way Forward', Marine Ornithology, vol. 34, 2006, pp. 1-5.

50 The Sydney Morning Herald, 3 June 2010, Business Day, p. 4. 


\section{References}

Aguilar Ibarra, Alonso, Chris Read and Andy Thorpe, 'The Political Economy of Marine Fisheries Development in Peru, Chile and Mexico', Journal of Latin American Studies, vol. 32, 2000, pp. 503-27.

Anderson, Steve, 'Chilean coastal fishermen protest depletion of hake', The Santiago Times, 26 October, 2007. http://www.santiagotimes.cl/index, accessed 2 October 2011.

Aranda, Martín, 'Developments on fisheries management in Peru: The new individual vessels quota system for the anchoveta fishery', Fisheries Research, vol. 96, issues 2-3, March 2009, pp. 308-12.

Australian Bureau of Agriculture and Resource Economics, Australian Fisheries Statistics 2011, December 2012, p. 1. http://abare.gov.au, accessed 27 October 2013.

Australian Fisheries Management Authority, Annual Report 2008-09, Canberra, 2009.

Annual Report 2008-2009, Canberra, 2009.

Annual Report 2011-2012, Canberra, 2012.

Annual Report 2011-2012, Canberra, 2012.

Australian Government, 'Australia's proposal for a forest carbon market mechanism', March 2009, http://www.climatechange.gov.au/government/ initiatives/unfccc/submissions.aspx, accessed 22 February 2010.

Australian Government, Department of Agriculture, Fisheries and Aquaculture, Fishery status reports 2011, 18 December 2012, http://www.daff.gov.au/ abares/publications_remote_content/public, accessed 27 October 2013.

Australian Government, Department of Climate Change and Energy Efficiency, 'Action under the International Forest Carbon Initiative', http://www. climatechange.gov.au/government/initiatives/international-forest-carboninitiative/action.aspx, accessed 14 December 2010.

—, 'International Forest Carbon Initiative', http://www.climatechange. gov.au/government/initiatives/international-forest-carbon-initiative.aspx, accessed 22 January 2010.

Australian Government, Department of Sustainability, Environment, Water, Population and Communities, Australian Marine Mammal Centre, http:// www.marinemammals.gov.au/home, accessed 27 October 2013. 
Australian Labor Party, National Platform and Constitution 2004, http://www. alp.com, accessed 27 October 2013.

Australian Marine Mammal Centre: Southern Ocean Research Partnership. http://www.marineanimals.gov.au/southern-ocean-research-partnershipssorp, accessed 27 October 2013.

'Closing Statement of the Fourth Meeting of the Coordinating Committee of the Valdivia Group, Wellington', 24-5 June 1998. http://www.dfat.gov.au/ environment/valdivia, accessed 27 October 2013.

Cooper, J., et al., 'The Agreement on the Conservation of Albatrosses and Petrels: Rationale, History, Progress and the Way Forward', Marine Ornithology, vol. 34 2006, pp. 1-5.

Darby, Andrew, 'Decision will bring tectonic shift in whaling politics.' The Age, 17 July 2013, http:/www.theage.com.au/federal-politics/political-opinion/ decision-will-bring-tectonic-shift-in-whaling-politics-20130717-2q351. html\#ixzz2cYh2HIWE, accessed 27 October 2013.

Darby, Andrew, 'Fight to turn tide of trash crashing on wild shores', The Sydney Morning Herald, 12-13 April, 2013, p. 7. http://www.smh.com.au/ environment/conservation/fight-to-turn-tide-of-trash-crashing-on-wildshores-20130412-2hquu.html, accessed 27 October 2013.

Devaney, Patricia Lee, 'Regional Fisheries Management Organizations: Bringing Order to Disorder', http://www.pon.org/downloads/ien14_4Devaney, accessed 27 October 2013.

Dodds, Klaus, 'The geopolitics of regionalism: the Valdivia Group and southern hemispheric environmental co-operation', Third World Quarterly, vol. 19, no. 4, 1998, pp. 725-43.

Draft Report of the Planning Workshop of the Southern Ocean Research Project, Workshop held in Sydney, 23-26 March 2009.

'Ecuador Analysis', Marine Conservation Agreements: a Practitioner's Toolkit, http://www.mcatoolkit.org/Country_Analyses/Ecuador.html, accessed 27 October 2013.

Eliasch, Johan E. Climate Change: Financing Global Forests, London, Earthscan, 2008.

Erikson, Marcus, et al., 'Plastic pollution in the South Pacific subtropical gyre', Marine Pollution Bulletin, 68 (2013): 71-2, http://www.elsevier.com/locate/ marpobul, accessed 27 October 2013. 
FAO, Yearbook of Fishery Statistics 2010, Summary Tables, p. 15. ftp://ftp.fao. org/fi/stat/summary, accessed 27 October 2013.

'From catchment-to-reef continuum: Case studies from the Great Barrier Reef. A special issue', Editorial, Marine Pollution Bulletin 2012, 65, 2012, p. 77. Elsevier: http://www.elsevier.com/locate/marpolbul, accessed 27 October 2013.

Garrett, Peter, 'Progress made at the International Whaling Commission', Media release, Australian Government, 28 June 2010, PG/74, http://www. environment.gov.au/minister/archive/ env/2010/mr20100628.html accessed 25 May 2011.

Garrett, Peter, 'The Future of International Whale Conservation', Speech: Lowy Institute, Sydney, 18 February 2009, http://www.petergarrett.com.au.

Gianni, M., and W. Simpson, 'The Changing Nature of High Seas Fishing: how flags of convenience provide cover for illegal, unreported and unregulated fishing', Australian Department of Agriculture, Fisheries and Forestry, Canberra, 2005.

ICJ, 'Whaling in the Antarctic (Australia v. Japan: New Zealand Intervening): Conclusion of the Public Hearings: Court to Begin its Deliberations', Press Release No. 2013/16, International Court of Justice, The Hague, 17 July 2013: http://www.icj-cij.org/docket/files/148/17464.pdf, accessed 6 December 2013.

Latin American and Caribbean Forestry Commission, 'Forests and Climate Change - With a Special Focus on Climate Change Adaptation', TwentySixth Session, Guatemala City, 24-8 May 2010, FO:LACFC/2010/6, http:// www.rlc.fao.org/es/comisiones/coflac/2010/pdf/lacfc-6e.pdf, accessed 20 June 2010.

Macintosh, Andrew, 'Reducing emissions from deforestation and forest degradation in developing countries: A cautionary tale from Australia', the Australia Institute, Policy Brief, No. 12, 2010.

Martinez, Elodie, et al., 'Floating marine debris surface drift: Convergence and accumulation toward the South Pacific subtropical gyre', Marine Pollution Bulletin. 58, 2009, pp. 1347-55.

Scientific and Technical Advisory Board, Marine Debris as a Global Environmental Problem, Washington, DC November 2011.

'Summary of the Oceans Day at Cancún, 4 December 2010', http://www.iisd.ca/ climate/cop16, accessed 27 October 2013. 
'Summary of the Resumed Review Conference of the UN Fish Stocks Agreement: 24-28 May 2010', Earth Negotiations Bulletin, vol. 7, no. 65, 31 May 2010. http://www.iisd.ca/download/pdf/enb0765e.pdf, accessed 27 October 2013.

Symes, David, and Jeremy Phillipson, 'Whatever became of social objectives in fisheries policy?', Fisheries Research, 95, 2009, pp. 1-5, http://www.elsevier. com/locate/fisheries, accessed 27 October 2013.

Taylor, Lenore, 'Whaling compromise would break election promise', The Sydney Morning Herald, 3 April 2010, http://www.smh.com.au/environment/whalewatch/whaling-compromise-would-break-election-promise-20100402-rjy5. html, accessed 27 October 2013.

UN General Assembly, Sixty-fifth session, Agenda item 75 (a), Oceans and the law of the sea, 'Letter dated 16 March 2010 from the Co-Chairpersons of the Ad Hoc Open-ended Informal Working Group to the President of the General Assembly'. A/65/68.

UN, FAO, Fisheries and Aquaculture Department, 'Port State Measures Agreement' . http://www.fao.org/fishery/topic/166283/en, accessed 27 October 2013.

UNFCCC (United Nations Framework Convention on Climate Change), 'Appendix 1 -Quantified economy-wide emissions targets for 2020', http://unfccc.int/ files/parties, accessed 2 February 2010.

Virgilio, Viana, 'Seeing REDD in the Amazon', Tiempo, 73, 2009, p. 5.

World People's Conference on Climate Change and the Rights of Mother Earth, http://pwccc.wordpress.com/, accessed 17 August 2010. 
This text taken from Australia and Latin America: Challenges and Opportunities in the New Millennium, Edited by Barry Carr \& John Minns, published 2014 by ANU Press, The Australian National University, Canberra, Australia. 